\title{
Nutrient Fluxes and Sediments Composition in El Mex Bay and Surround Drains, Alexandria, Egypt
}

\author{
Mohamed Attia Shreadah', Mamdouh Saad Masoud'2, Abdel-Rhman Mosaad Khattab33, \\ Gehan Mohamed El Zokm ${ }^{*}$ \\ ${ }^{1}$ National Institute of Oceanography and Fisheries, Alexandria, Egypt \\ ${ }^{2}$ Faculty of Science, Alexandria University, Alexandria, Egypt \\ ${ }^{3}$ Faculty of Science, Al-Azhar University, Cairo, Egypt \\ Email: gehanelzokm@yahoo.com
}

Received 16 March 2015; accepted 4 May 2015; published 8 May 2015

Copyright (C) 2015 by authors and Scientific Research Publishing Inc.

This work is licensed under the Creative Commons Attribution International License (CC BY).

http://creativecommons.org/licenses/by/4.0/

\section{(c) (7) Open Access}

\section{Abstract}

The regeneration of pore water (PW) nutrients was investigated and the contribution of benthic nutrient fluxes to the overlying bottom water (BW) was examined. Dissolved inorganic nutrients $\left(\mathrm{NO}_{2}^{-}, \mathrm{NO}_{3}^{-}, \mathrm{PO}_{4}^{3-}\right.$ and $\mathrm{SiO}_{4}^{4-}$ ) were measured in $\mathrm{PW}$ and $\mathrm{BW}$ in $\mathrm{El} \mathrm{Mex} \mathrm{Bay} \mathrm{and} \mathrm{surround} \mathrm{drains}$ during spring 2010. Nutrient concentrations gradiance in PW with overlying seawater were evaluated according to Fick's Law. Average inorganic nutrient fluxes were estimated using the pore water gradient concentration across the sediment-water interface. Calculated nutrient fluxes had averages of -7.24, -1.36, -7.86 and -1.33 in El Mex Bay. Additionally, the fluxes in the drains were $-34.39,-32.28,-53.20$ and $-117.6 \mathrm{mg} \cdot \mathrm{m}^{-2}$. $\mathrm{day}^{-1}$ for $\mathrm{NO}_{3}^{-}, \mathrm{NO}_{2}^{-}, \mathrm{PO}_{4}^{3-}$ and $\mathrm{SiO}_{4}^{4-}$, respectively. Mineralogical studies of sediment samples by using IR, X-ray analysis were carried out to identify the chemical structure of sediments. The results revealed that calcite, aragonite and quartz are the dominant minerals. On the other hand, differential thermal analysis (DTA) was used to evaluate and discuss different kinetic parameters such as $\mathrm{Ea}^{\#}, \Delta \mathrm{G}^{\#}, \Delta \mathbf{H}^{\#}, \Delta \mathrm{S}^{\#}, \mathrm{Z}$ and Tm support the view of the extra stability of these sediments.

\section{Keywords}

Nutrient Fluxes, IR-X-Ray-DTA, Sediments, El Mex Bay, Alexandria, Egypt

\section{Introduction}

During the last century, the Egyptian coastal areas along the Mediterranean sea were strongly impacted by the

"Corresponding author.

How to cite this paper: Shreadah, M.A., Masoud, M.S., Khattab, A.-R.M. and El Zokm, G.M. (2015) Nutrient Fluxes and Sediments Composition in El Mex Bay and Surround Drains, Alexandria, Egypt. American Journal of Analytical Chemistry, 6, 513-527. http://dx.doi.org/10.4236/ajac. 2015.66050 
development of anthropogenic activities on their shores and the subsequent inputs of inorganic including nutrients and organic pollutants [1]-[7]. Although these releases were significantly reduced during recent decades because of regulations, contaminants accumulated in the sediments over time [8]-[19]. These sediments now constitute a potential source of contaminants for the water column that could alter the water quality and threaten aquatic organisms [20]-[30]. Understanding the processes controlling the dynamics of contaminants in the sediment, improving our knowledge of the environmental risk induced by contaminated sediments and appropriately orientating the action of politics and managers, is thus a challenge for the next decades [31].

Nutrient fluxes at the sediment-water interface can indeed influence or regulate the nutrient composition of the water column since the sediment can behave as a sink or as a source of inorganic nitrogen, phosphorus and silicate through different biogeochemical processes [32]. Processes involved in nutrient transfer are reversible, quick and differ with season and sediment types. Since many pollutants originally introduced into the water column have affinities for sediment particles, the pore water is expected to be more polluted than bottom water [1]. Nutrient salts had been introduced to El Mex Bay mainly through the surrounded drains [33].

Sediments may originate from a number of sources. The proportions of sediments from different sources at any particular location will depend on a variety of hydrological and geological factors, e.g. circulation patterns, tidal movement, weathering conditions and source rocks. It was pointed out that the two extreme sources of sediments i.e. landward and seaward, together with intermediate sources, such as river mouths slope impose severe limitations on the geochemical interpretation of sedimentary processes [34]. The most important sedimentary and chemical interactions may be subdivided into two aspects; 1) the modification of sedimentary detritus during its transport to the seas; and 2) the modification of sediments after deposition (digenetic changes). IR, $\mathrm{X}$ ray and DTA are used to study sediment compositions.

\section{Materials and Methods}

\subsection{Study Area}

El-Mex Bay is part of the Alexandria coast on the Mediterranean Sea. It is adjacent to the center of Alexandria that is populated with about six million inhabitants and is considered as one of the main fishing sources in Egypt. It extends for about $15 \mathrm{~km}$ between El-agamy head land in the west and the western harbor to the east and from the coast to a depth line of about $15 \mathrm{~km}$. the bay has a mean depth of about $10 \mathrm{~m}$ and surface area of about 19.4 $\mathrm{km}^{2}$ (Figure 1). It is a highly polluted area, the major types of pollution sources are domestic sewage, industrial waste water, and agricultural run-off, through lake out lets, and river discharged and oil pollution. El-Mex Bay receives mixed agricultural run-off from lake Mariut through El-max pumping station and El-umum drain, industrial water from chloro-alkali plant, tanneries and slaughterhouse, also, air borne particles from the fumes of adjacent industrial plants including a cement factory [35]-[42].

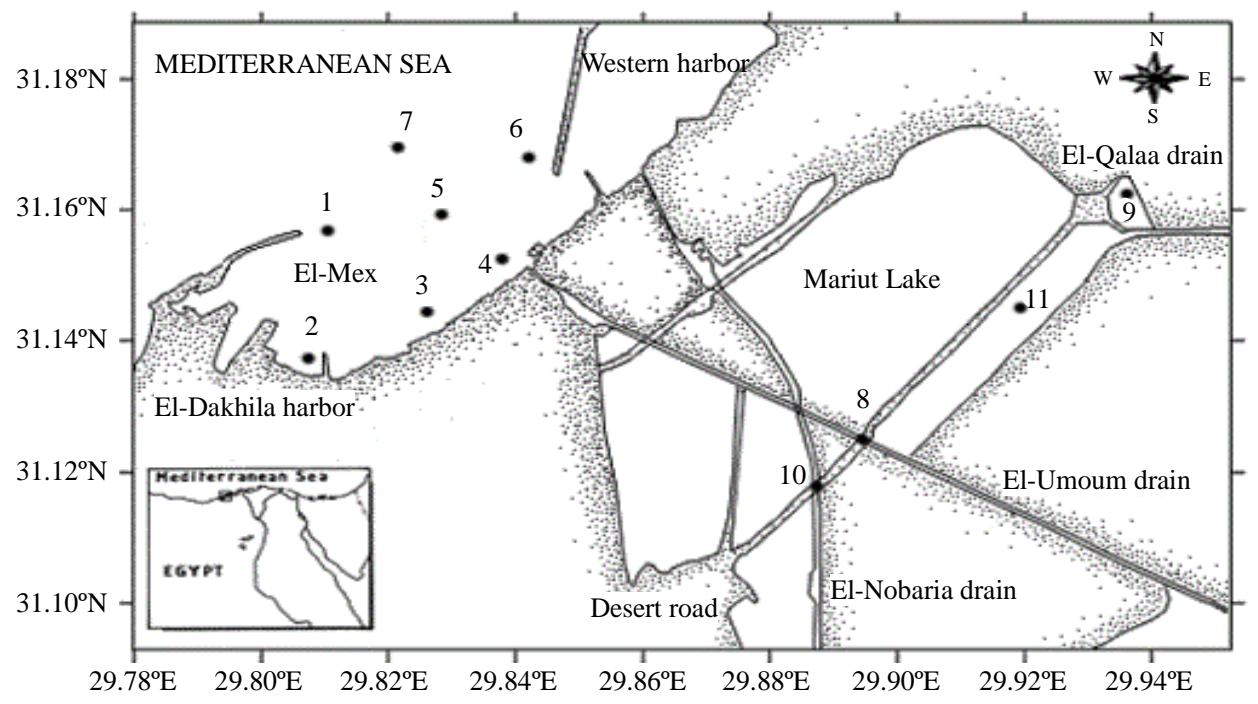

Figure 1. El-Mex Bay and surround drains showing sampling stations. 


\subsection{Sampling}

\subsubsection{Bottom Water}

Bottom water samples were collected using a five liters Nisken's plastic bottle provided with a thermometer.

\subsubsection{Grab Surface Sediments}

Surficial sediments were collected in April 2010 from seven stations, distributed at El-Mex Bay of Alexandria, and four stations in the drains (El-Umum, El-Noubaria, El-Qalah and Mariout Lake) as shown in Figure 1 using Ekman grab sampler.

\subsection{Methods}

\subsubsection{Bottom Water}

Nutrient salts were spectrophotometrically determined using a double beam spectrophotometer (UV VISSPEKOL ${ }^{\circledR} 1300 / 1500$ single beam), according to the methods described by Strickland and Parsons [43].

\subsubsection{Interstitial Waters}

\section{a) Extractions of Interstitial Waters from Sediments}

The choice of the techniques used for extraction the interstitial water from sediments is usually governed by the nature of sediments and available facilities as follows; 1-In case of silty sediment fractions, the squeezer technique was used [44]. The squeezer was lined with Teflon as recommended by Patterson and Settle [45]; centrifugation for muddy sediments occurred at 10.000 rpm for about 20 minutes [46]; and 2-by filtration on a glass fiber filter, in case of sand sediment fractions.

\section{b) Nutrient Salts Analysis}

$\mathrm{NO}_{2}^{-}, \mathrm{NO}_{3}^{-}, \mathrm{PO}_{4}^{3-}$ and $\mathrm{SiO}_{4}^{4-}$ were measured in small volumes of the interstitial waters $(5-10 \mathrm{ml})$. Nutrient salts were spectrophotometrically determined using a double beam spectrophotometer (UV VIS-SPEKOL ${ }^{\circledR}$ 1300/1500 single beam) according to Strickland and Parsons [43].

\subsubsection{Sediments}

\section{a) Preparation of Samples}

After extraction of the interstitial waters, sediment samples were subjected to air dryng, by spreading them on clean plastic sheets. All these were made inside a clean cabinet. The quartering was made using the familiar cone and quarter technique. Air dried samples were placed inside an electric oven for overnight at $70^{\circ} \mathrm{C}$. One half of each dry sediment sample was lightly hand ground in an a agate mortar, sieved through a screen of 0.2 $\mathrm{mm}$ mesh size and kept in clean and well stopper polyethylene vials to be ready for geochemical analysis. The remainder of each dry sample was used for the mechanical or grain size analysis.

b) Grain-size and Granulemetric Analysis

The sediment samples were subjected to grain size analysis according to the method described by Folk [47]. The phi unit is equivalent to the $-\log 2 \mathrm{x}$. where $\mathrm{x}$ is the grain size in millimeter. $25 \mathrm{~g}$ of the dry sediment samples were taken for mechanical analysis, which was carried out using a standard set of sieves in a Ro-Top shaker for 20 min, the sieves were arranged from top to bottom in a one phi order as follows: $-2,-1,0,1,2,3$ and 4 phi, which correspon 4, 2, 1, 0.5, 0.25, 0.125 an $0.063 \mathrm{~mm}$ respectively. The collected sieve fractions were accurately weighted. The samples containing an appreciable amount of mud (more than 10\%) were subjected to pipette analysis as described by Krumbein and Pettijhon [48]. Each fraction of sucking pipette was dried and weighted to the nearest $0.0001 \mathrm{~g}$.

\section{c) Infrared Spectra (IR) Analysis}

Sediment samples were analyzed by Infrared Perkin-Elmer R79521, Ratio Recording FT-IR System Spectrophotometer (USA) that was available from central lab unit, National Institute of Oceanography and Fisheries (NIOF), Alexandria, Egypt.

\section{d) $\mathrm{X}$-ray analysis}

The data were obtained using (Pentater Link Oxford, Link ISIS) and JEOL JSM-5300 Scanning electron Microscope. Specttra taken in the range of 1 - $8 \mathrm{Kev}$. The instrument is available in faculty of science Alexandria University.

\section{e) Thermal analysis}

Differential thermal analysis (DTA) was carried using a Shimadzu DTA-50 with platinum cell that was 
available from the fine analysis center, Cairo University, Egypt. The rate of heating was $10^{\circ} \mathrm{C} / \mathrm{min}$. Dry nitrogen was followed over the sample at a rate of $20 \mathrm{ml} / \mathrm{min}$.

\subsection{Fluxes Calculations}

Due to the ever-increasing loads of nitrogen and phosphorus from aquaculture, lots of dissolved or granular nitrogen and phosphorus accumulate on the surface of the sediments by flocculation, adsorption and sedimentation, resulting in growing contents of nitrogen and phosphorus in the overlying waters. This indicates that in El Mex Bay, a large amount of nitrogen and phosphorus from the sediments is released into the overlying water [33] [37]-[39]. It is obviously clear that there are concentration gradients of nitrogen and phosphorus in pore water along the sediment depth. The diffusion fluxes of nitrate, nitrite and dissolved reactive phosphate (DRP) and silicate across sediment-water interface can be computed by Fick's first law. Fluxes of ammonia, nitrite, nitrate, phosphate and silicate between sediments and the overlying water were calculated according to Fick's first law of diffusion as follows:

$$
J=-\phi \times D_{s} \times\left(\frac{\mathrm{d} c}{\mathrm{~d} x}\right)
$$

where $J$ is the flux $\left(\mu \mathrm{mol} \cdot \mathrm{m}^{-2} \cdot \mathrm{d}^{-1}\right), \phi$ is the mean porosity of surface sediment $\left(\mathrm{ml}_{\text {pore water }} / \mathrm{cm}_{\text {sediment }}^{3}\right.$; dimensionless) $=0.7$ for El Mex Bay (unpublished data), $D_{s}$ is the diffusion coefficient $\left(\mathrm{m}^{2} \cdot \mathrm{d}^{-1}\right)$, and $\mathrm{dc} / \mathrm{d} z$ is the concentration gradient in the overlying bottom waters $\left(\mu \mathrm{mol} \cdot \mathrm{m}^{-4}\right)$.

$$
D_{s}=D_{0} / \phi F \quad[49]
$$

where $D_{0}$ is the diffusive coefficient at infinite dilution, and the values for $\mathrm{NO}_{2}-\mathrm{N}, \mathrm{NO}_{3}-\mathrm{N}, \mathrm{PO}_{4}-\mathrm{P}, \mathrm{SiO}_{4}-\mathrm{Si}$ were 18.3, 17.2, 9.25, $7.07 \times 10^{-6}\left(\mathrm{~cm}^{2} / \mathrm{sec}\right)$ at $21^{\circ} \mathrm{C}$ [50] and $F$ is the sediments resistivity [51].

Krom and Berne [49], gives an empirical relationship between $F$ and $\phi$ according to:

$$
F=\frac{1}{\phi^{m}}
$$

For $\phi \leq 0.7, m=2$ is a better fit to the data. These data imply that $m$ is not constant over the entire range of porosities possible in a particular sediment type undergoing natural compaction.

The diffusion flux $\left(J_{i}\right)$ for phosohorus is estimated by Fick's law according to:

$$
J_{i}=-D_{o i} \phi^{2}\left(\mathrm{~d} c_{i} / \mathrm{d} x\right)
$$

Therefore: $J_{i}=-9.25 \times 10^{-6} \times(0.7)^{2} \times\left(\mathrm{d} c_{i} / \mathrm{d} x\right) \mathrm{cm}^{2} / \mathrm{sec}$

$$
\frac{\mathrm{d} c}{\mathrm{~d} x}=\left(\frac{\mu M}{L}\right) \mathrm{cm}^{-1}=10^{-9} \times 31(\text { at.wt.of P }) \mathrm{g} / \mathrm{cm}^{4}
$$

where $\mathrm{d} c_{i}=[\mathrm{P}]_{i}-[\mathrm{B}]_{i}$

$$
\begin{aligned}
J\left(\mathrm{NO}_{2}-\mathrm{N}\right) & =-\left[18.3 \times 10^{-6} \times(0.7)^{2} \times\left(\mathrm{d} c_{i} / 5\right)\right] \mathrm{cm}^{2} / \mathrm{sec}\left(10^{-9} \times 14\right) \mathrm{g} \mathrm{N} \mathrm{cm}^{-4} \\
& =-2.17 \times 10^{-2} \mathrm{~d} c_{i} \mathrm{mg} \mathrm{N} \mathrm{m}{ }^{-2} \cdot \mathrm{day}^{-1} \\
J\left(\mathrm{NO}_{3}-\mathrm{N}\right) & =-\left[17.2 \times 10^{-6} \times(0.7)^{2} \times\left(\mathrm{d} c_{i} / 5\right) \mathrm{cm}^{2} / \mathrm{sec}\right]\left(10^{-9} \times 14\right) \mathrm{g} \mathrm{N} \mathrm{cm}^{-4} \\
& =-2.04 \times 10^{-2} \mathrm{~d} c_{i} \mathrm{mg} \mathrm{N} \mathrm{m}{ }^{-2} \cdot \mathrm{day}^{-1} \\
J\left(\mathrm{PO}_{4}-\mathrm{P}\right) & =-\left[9.25 \times 10^{-6} \times(0.7)^{2} \times\left(\mathrm{d} c_{i} / 5\right) \mathrm{cm}^{2} / \mathrm{sec}\right]\left(10^{-9} \times 31\right) \mathrm{g} \mathrm{P} \mathrm{cm}^{-4} \\
& =-2.43 \times 10^{-14} \times \mathrm{d} c_{i} \mathrm{~g} \mathrm{P} \mathrm{cm}^{-2} \cdot \mathrm{sec}^{-1}=-1.875 \times 10^{-2} \times \mathrm{d}_{i} \mathrm{mg} \mathrm{P} \mathrm{m}^{-2} \cdot \mathrm{day}^{-1} \\
J\left(\mathrm{SiO}_{4}-\mathrm{Si}\right) & =-\left[7.07 \times 10^{-6} \times(0.7)^{2} \times\left(\mathrm{d} c_{i} / 5\right) \mathrm{cm}^{2} / \mathrm{sec}\right]\left(10^{-9} \times 28\right) \mathrm{g} \mathrm{Si} \mathrm{cm}^{-4} \\
& =-1.68 \times 10^{-2} \mathrm{~d} c_{i} \mathrm{mg} \mathrm{Si} \mathrm{m}^{-2} \cdot \mathrm{day}^{-1}
\end{aligned}
$$


Sakamaki et al., [52] reported that the sediment water exchange fluxes of $\mathrm{NO}_{3}^{-}$are controlled by both benthic microalgal uptake and the release from sediments that is largely affected by the overlying water quality. The authors added that at high concentration in low tide the benthic microalgal actively absorbs dissolved inorganic nitrogen, especially $\mathrm{NO}_{3}^{-}$that is much higher than $\mathrm{NH}_{4}^{+}$and high transfer of $\mathrm{NO}_{3}^{-}$from water to sediments occurs. In this case, the activity of algae is also considerably affected by the high concentration of $\mathrm{NO}_{3}^{-}$and the uptake fluxes largely change during the day time. However, at low concentration in high tide, a high release from sediments to water occurs and predominates in the sediment-water fluxes.

\section{Results and Discussion}

\subsection{Nutrient Exchange between Pore and Overlying Water}

Measurements of dissolved inorganic nutrients $\left(\mathrm{NO}_{2}^{-}, \mathrm{NO}_{3}^{-}, \mathrm{PO}_{4}^{3-}\right.$ and $\left.\mathrm{SiO}_{4}^{4-}\right)$ in $\mathrm{PW}$ and $\mathrm{BW}$ were performed in El Mex Bay and surround drains during Spring 2010, and illustrated in Table 1. The nutrient salts concentrations in drains are much higher than El Mex Bay stations because of agriculture and domestic wastes.

When nutrients from outer sources are discharged into water bodies, a great deal of nitrogen and phosphorus accumulates in sediments and their concentrations may be up to 50 to 500 times that in the overlying water [53]. The results showed significantly higher nutrient concentrations in the PW than their corresponding BW as shown in Table 1. The average concentrations in PW were about 44.8, 37.6, 113.45 and 15.76 times higher than the average values reported in the $\mathrm{BW}$ for $\mathrm{NO}_{3}^{-}, \mathrm{NO}_{2}^{-}, \mathrm{PO}_{4}^{3-}$ and $\mathrm{SiO}_{4}^{4-}$ respectively in $\mathrm{El}$ Mex Bay. The large increase in nutrient loading has led to the impairment of many water bodies globally [54]. This included the eutrophication of water bodies that can lead to dissolved-oxygen depletion, species shifts, and fish kills [55]. Nutrient concentrations in the PWin the present study had higher average values than reported by Nessim et al., [56] in Eastern Harbour (2.8. 14.2 and 25 for $\mathrm{NO}_{2}^{-}, \mathrm{PO}_{4}^{3-}$ and $\mathrm{SiO}_{4}^{4-} \mu \mathrm{ML}^{-1}$, respectively).

Nutrient diffusive fluxes calculated in the present study were illustrated in Table 2 that had averages of -7.24 , $-1.36,-7.86$ and -1.33 in the upword diriction, however, in the drains were $-34.39,-32.28,-53.20$ and -117.6 $\mathrm{mg} \cdot \mathrm{m}^{-2} \cdot$ day $^{-1}$ for $\mathrm{NO}_{3}^{-}, \mathrm{NO}_{2}^{-}, \mathrm{PO}_{4}^{3-}$ and $\mathrm{SiO}_{4}^{4-}$, respectively. Abu El Khair et al., [57] reported difussive fluxes of $-0.053,-0.445$ and $-1.77 \mathrm{mg} \cdot \mathrm{m}^{-2}$. day ${ }^{-1}$ for $\mathrm{NO}_{3}^{-}, \mathrm{PO}_{4}^{3-}$ and $\mathrm{SiO}_{4}^{4-}$, respectively in Abu Qir Bay. Additionaly, Farragala [58] reported nutrients diffusive fluxes of $-0.01,+0.007$ and $-0.143 \mathrm{mg} \cdot \mathrm{m}^{-2} \cdot$ day $^{-1}$ for

Table 1. Nutrient concentrations in BW and PW $\left(\mu \mathrm{ML}^{-1}\right)$ of El-Max bay and surrounded drains during spring 2010.

\begin{tabular}{|c|c|c|c|c|c|c|c|c|}
\hline \multirow[t]{2}{*}{ St.No. } & \multicolumn{2}{|c|}{ Nitrite } & \multicolumn{2}{|c|}{ Nitrate } & \multicolumn{2}{|c|}{ Phosphate } & \multicolumn{2}{|c|}{ Silicate } \\
\hline & BW & PW & BW & PW & BW & PW & BW & PW \\
\hline 1 & ND & 24.51 & 1.80 & 4.57 & 6.44 & 911.40 & 4.26 & 51.96 \\
\hline 2 & 0.38 & 49.03 & 1.43 & 292.85 & 2.66 & 75.95 & 5.33 & 31.17 \\
\hline 3 & 6.15 & 28.02 & 8.25 & 317.79 & 8.54 & 455.70 & 13.06 & 83.13 \\
\hline 4 & 0.83 & 178.60 & 9.83 & 53.45 & 0.77 & 260.40 & 3.92 & 114.31 \\
\hline 5 & 0.38 & 52.53 & 3.34 & 44.04 & 5.88 & 282.10 & 3.96 & 62.35 \\
\hline 6 & 0.38 & 17.51 & 31.17 & 1175.50 & 1.12 & 32.55 & 3.92 & 31.17 \\
\hline 7 & 0.50 & 98.06 & 12.05 & 663.50 & 0.70 & 943.95 & 3.11 & 218.22 \\
\hline Average & 1.43 & 64.04 & 9.70 & 364.53 & 3.73 & 423.15 & 5.37 & 84.62 \\
\hline 8 & 12.33 & 487.83 & 20.00 & 591.96 & 9.66 & 2598.58 & 77.59 & 4809.25 \\
\hline 9 & 0.63 & 4024.85 & 5.00 & 2202.88 & 53.90 & 1703.45 & 49.84 & 2107.42 \\
\hline 10 & 1.38 & 479.07 & 2.86 & 2453.98 & 1.68 & 971.08 & 6.18 & 1405.99 \\
\hline 11 & ND & 978.11 & 40.00 & 1562.72 & 10.22 & 6151.95 & 111.00 & 19929.08 \\
\hline Average & 4.78 & 1492.47 & 16.96 & 1702.89 & 18.87 & 2856.26 & 61.15 & 7062.94 \\
\hline
\end{tabular}

8-El-Umum Drain, 9-El-Qalaa Drain 10_El-Noubaria Drain and 11-Mariut Lake. 
Table 2. Fluxes of nitrite, nitrate, phosphate and silicate $\left(\mathrm{mg} \cdot \mathrm{m}^{-2} \cdot\right.$ day $\left.^{-1}\right)$ from sediments in El-Mex bay and surround drains during spring 2010.

\begin{tabular}{|c|c|c|c|c|c|c|c|c|}
\hline \multirow{3}{*}{ St.No. } & \multirow{2}{*}{\multicolumn{2}{|c|}{$\begin{array}{c}\text { Nitrite } \\
\mathrm{D}_{0}=18.3 \times 10^{-6}\end{array}$}} & \multirow{2}{*}{\multicolumn{2}{|c|}{$\begin{array}{c}\text { Nitrate } \\
\mathrm{D}_{0}=17.2 \times 10^{-6}\end{array}$}} & \multirow{2}{*}{\multicolumn{2}{|c|}{$\begin{array}{c}\text { Phosphate } \\
\mathrm{D}_{0}=9.25 \times 10^{-6}\end{array}$}} & \multirow{2}{*}{\multicolumn{2}{|c|}{$\begin{array}{c}\text { Silicate } \\
\mathrm{D}_{0}=7.07 \times 10^{-6}\end{array}$}} \\
\hline & & & & & & & & \\
\hline & dc & $\mathrm{J}$ & dc & $\mathrm{J}$ & dc & $\mathrm{J}$ & dc & $\mathrm{J}$ \\
\hline 1 & 24.51 & -0.53 & 2.77 & -0.06 & 904.96 & -16.97 & 47.7 & -0.80 \\
\hline 2 & 48.65 & -1.06 & 291.42 & -5.94 & 73.29 & -1.37 & 25.84 & -0.43 \\
\hline 3 & 21.87 & -0.47 & 309.54 & -6.31 & 447.16 & -8.38 & 70.07 & -1.18 \\
\hline 4 & 177.77 & -3.86 & 43.62 & -0.89 & 259.63 & -4.87 & 110.39 & -1.85 \\
\hline 5 & 52.15 & -1.13 & 40.7 & -0.83 & 276.22 & -5.18 & 58.39 & -0.98 \\
\hline 6 & 17.13 & -0.37 & 1144.33 & -23.34 & 31.43 & -0.59 & 27.25 & -0.46 \\
\hline 7 & 97.56 & -2.12 & 651.45 & -13.29 & 943.25 & -17.69 & 215.11 & -3.61 \\
\hline Average & 62.61 & -1.36 & 354.83 & -7.24 & 419.42 & -7.86 & 79.25 & -1.33 \\
\hline 8 & 475.5 & -10.32 & 571.96 & -11.67 & 2588.92 & -48.54 & 4731.66 & -79.49 \\
\hline 9 & 4024.22 & -87.33 & 2197.88 & -44.84 & 1649.55 & -30.93 & 2057.58 & -34.57 \\
\hline 10 & 477.69 & -10.37 & 2451.12 & -50.00 & 969.4 & -18.18 & 1399.81 & -23.52 \\
\hline 11 & 978.11 & -21.22 & 1522.72 & -31.06 & 6141.73 & -115.16 & 19818.1 & -332.94 \\
\hline Average & 1487.69 & -32.28 & 1685.93 & -34.39 & 2837.39 & -53.20 & 7001.79 & -117.63 \\
\hline
\end{tabular}

8-El-Umum Drain, 9-El-Qalaa Drain 10-El-Noubaria Drain and $11-$ Marriut Lake. $\mathrm{D}_{0}$; is the diffusive coefficient at infinite dilution at $21^{\circ} \mathrm{C}$ cited from Zhang et al. [50].

$\mathrm{NO}_{2}^{-}, \mathrm{NO}_{3}^{-}$and $\mathrm{PO}_{4}^{3-}$, respectively. Comparing the results of the present study with that reported by Abu Khair et al., [57] and Faragalla [58] revealed that nutrient upword diffusive fluxes in El Mex Bay had significant higher values that recorded in Abu Qir Bay and Eastern Harbour.

$\mathrm{NO}_{2}^{-}$and $\mathrm{NO}_{3}^{-}$diffused from pore water with high values refered to that immobilization rate (Nitrification) of these ions is greater than consumption rate (denitrification). This reflects the dominant of oxidation reaction in pore water in the study area. Dissolved Oxygen in the bottom water in the study area during Spring was 6.61 $\mathrm{mg} / \mathrm{L}$ [33], however DO was low most of the year in the Eastern Harbour 3.2 - $5.7 \mathrm{mg} / \mathrm{L}$ [59].

During Spring, when the surface cools, a point is reached at which the temperature of the surface and bottom are equal. The disappearance of thermal stratification cause the entire body of water to behave as a hydrological unit, and the resultant mixing is known as overturn. During the overturn, the chemical and physical characteristics of any body of water becomes much more uniform, and a number of chemical, physical, and biological changes may result. Biological activity may increase from the mixing of nutrients. Higher and negative flux values (upword flow from sediment to over laying water) of all nutrients could be attributed to higher sediment organic matter content and high biological activity. Delange [60] suggested at least three scenarios for ultimate source of phosphorus; Organic-P cracking, the release of phosphorus from phosphor-lipids and other high energy phosphorus compounds from plankton debris by microbial action at the sediment-water interface; dissolution of fish debris; and the release of phosphorus sorbed onto iron oxyhydroxides, i.e. FeOOH sorbs phosphorus from bottom water and from upward diffusion PW phosphate and incorporate below the oxic surface sediments by burial or mixing, are reduced to $\mathrm{Fe}^{2+}$, releasing the sorbed phosphate. Noel [61] reported the sediment compartment plays a role in the water column phosphate contents and should be considered as a buffer able to both store and release phosphate according to the conditions. However through exchanges at the sediment-water interface and migration of the phosphate, The exchange process that in spring, biological activity was more stressed and a steady equilibrium cannot be reached.

\subsection{Grain size (Texture) Analysis}

Mean grain size and the median diameter may reflect the general characteristics of granule metric composition 
of sediment. While the values of skewness and kurtosis reflects the uniformity of distribution of sediment composition. The distribution of sediment composition depends on the equilibrium between gravity of sediments and water forces. In the present study, the results of the grain size analysis of the grab sediments of the study area, (Table 3). Most of the sediments of El-Mex Bay are rich in sand fraction. The respective ranges of silt are from $0.00 \%$ at station 3 to $91.20 \%$ at station 5 . For clay fraction, the respective ranges were $0.00 \%$ at station 6,7 (front of western harbor and Far $1200 \mathrm{~m}$ from Station 4) to 9.12\% at station 1 (El-Dekhila Head). The respective ranges of sand are $0.00 \%$ at station 1 (El-Dekhila Head) to 100\% at stations 3, 4, 6 and 7 (Petrochemicals company, in front of El-Umum drain and western harbor and far $1200 \mathrm{~m}$ from EL-Umum drain).

El-Mex sediments contained appreciable amounts of tubeworm skeletons of some calcareous organisms, bivalve shell fragments (placipoda, plyciopoda and gastropod) and gravel. The texture of sediments was mainly sandy, with some muddy sediments in stations 1,2 and 5 (Table 3). These sediments are exposed more to the sea and current actions leading to such good sorting and dominance of the coarser sandy fraction. The dominance is sandy mud sediments in the most stations. Most of the sediments of El-Mex drains are rich in silt fraction. The respective ranges of sand are from $2.36 \%$ at station 11 (El-Qalaa drain) to $39.30 \%$ at station 9 (El-Umum drain). Clay fraction ranged from $15.74 \%$ at station 9 (El-Umum drain) to $37.72 \%$ at station 8 (El-Noubaria drain). The ranges of slit are $44.97 \%$ at station 9 (El-Umum drain) to $77.06 \%$ at station 10 (Mariut Lake).

\subsection{Infrared Spectra (IR)}

IR curves are normally used in mineralogy for qualitative analysis and identification of different minerals, even complex mixtures. It is based on positions and shapes of absorption bands [62]. Spectra of all sediment samples are very nearly similar indicating that the constituents are almost the same. The main features of the sediment absorption spectra (Figure 2) showed a broad band within the range $3100-3600 \mathrm{~cm}^{-1}$ assigned for O-H stretching vibration of $\mathrm{H}_{2} \mathrm{O}$ which readily lost upon heating [62] [63]. These regions are mainly composed of calcareous sediment containing amorphous silica $\mathrm{SiO}_{2} \mathrm{nH}_{2} \mathrm{O}$ ) according to Degens [64].

A weak band within the range of $2300-2400 \mathrm{~cm}^{-1}$ is characteristic for absorption of carbonate minerals (calcite and magnesium calcite) according to Smolander et al., [62]. The samples gave weak bending vibration bands within the range of $1700-1800 \mathrm{~cm}^{-1}$, reflecting the deformation of water molecules in clay minerals [63] [65]. Furthermore, the spectra of all samples showed strong broad feature at $1400-1500 \mathrm{~cm}^{-1}$ characteristic for carbonate radical [62]. The in plane bending vibration band within the range $1030-1090 \mathrm{~cm}^{-1}$ for O-H in the sediment samples appears in all regions. A peak can be seen, especially at El-Mex and El-Qalaa around 2940

Table 3. Grain size analysis of El-Mex Bay and drains during spring 2010.

\begin{tabular}{|c|c|c|c|c|c|c|}
\hline \multirow{2}{*}{ Station No. } & Clay & Silt & Sand & Sediment type & Sorting & Sortig \\
\hline & \multicolumn{3}{|c|}{$\%$} & (Folk, 1974) & Coefficient (phi) & Type \\
\hline 1 & 9.12 & 90.88 & 0.00 & Silt & 1.12 & Poorly sorted \\
\hline 2 & 0.42 & 40.55 & 59.03 & Silty Sand & 1.01 & Poorly sorted \\
\hline 3 & 0.00 & 0.00 & 100.00 & Sand & 1.10 & Poorly sorted \\
\hline 4 & 0.00 & 0.00 & 100.00 & Sand & 1.20 & Poorly sorted \\
\hline 5 & 2.06 & 91.20 & 6.75 & Silt & 0.75 & Moderately sorted \\
\hline 6 & 0.00 & 0.00 & 100.00 & Sand & 0.98 & Moderately sorted \\
\hline 7 & 0.00 & 0.00 & 100.00 & Sand & 0.36 & Well sorted \\
\hline 8 & 37.72 & 54.90 & 7.39 & Silt Clay & 2.03 & Very poorly sorted \\
\hline 9 & 15.74 & 44.97 & 39.30 & Silty Sand & 2.53 & Very poorly sorted \\
\hline 10 & 18.36 & 77.06 & 4.57 & Silt & 1.45 & Poorly sorted \\
\hline 11 & 23.79 & 73.85 & 2.36 & Silty Sand & 1.76 & Poorly sorted \\
\hline
\end{tabular}

8-El-Umum Drain, 9-El-Qalaa Drain, 10—El-Noubaria Drain, and 11-Mariut Lake. 


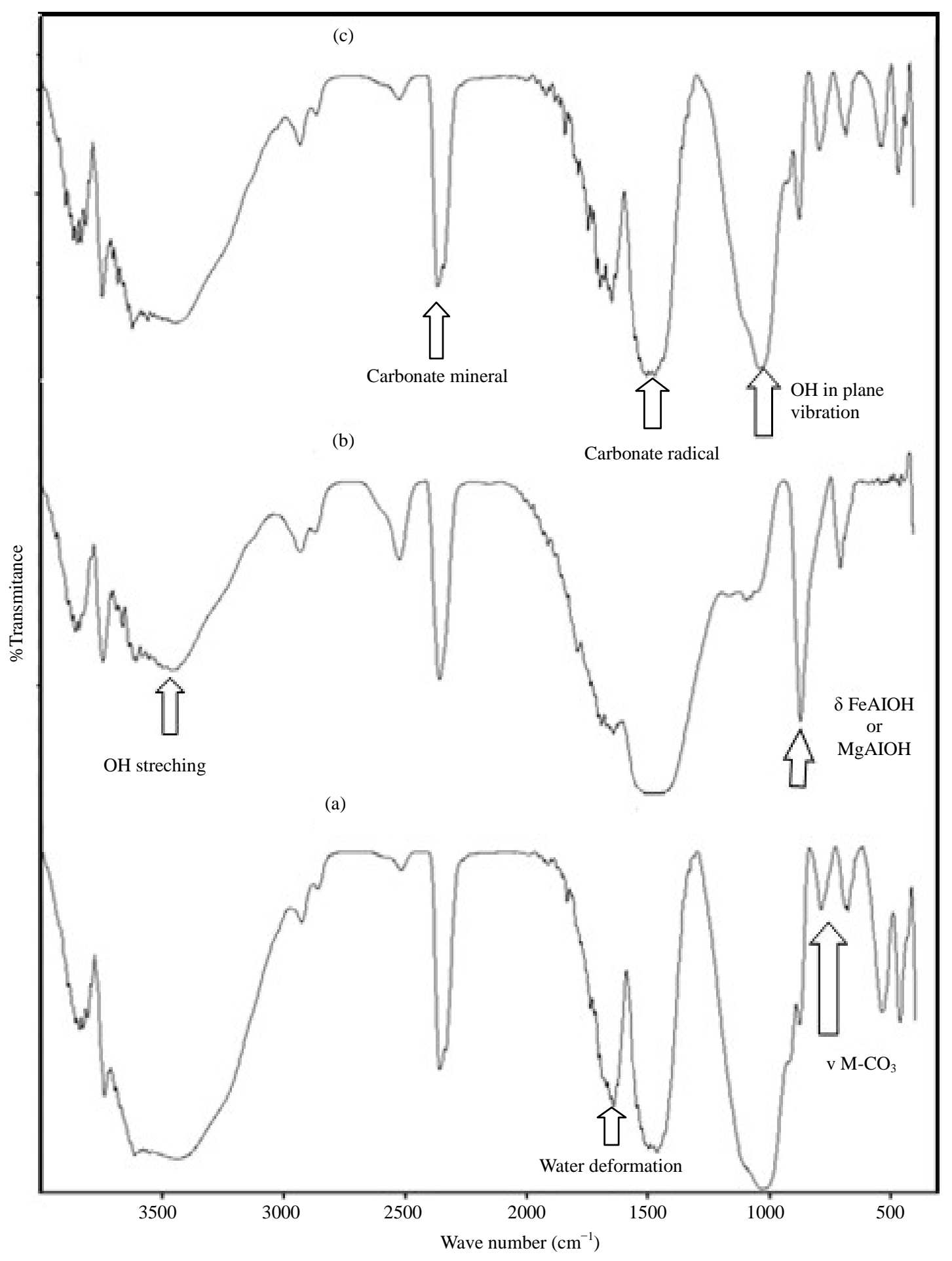

Figure 2. Infrared of sediment samples (a) Mariut Lake, (b) El-Mex, (c) El-Qalaa.

$\mathrm{cm}^{-1}$ could be attributed to the asymmetrical C-H stretching of methyl $\left(-\mathrm{CH}_{2}\right)$ groups being characteristic of aliphatic hydrocarbon [66]. The bands within the range of $780-800 \mathrm{~cm}^{-1}$ represent the bending in plane vibration band of $\mathrm{OH}$ groups for $\delta \mathrm{MgAlOH}$ [67]. Carbonate minerals in all sediments are identified by the wave number of $\mathrm{M}-\mathrm{CO}_{3}$ stretching band within the range of $650-700 \mathrm{~cm}^{-1}$. The symmetric Si-O-Si stretching appeared as weak bands at $460-500 \mathrm{~cm}^{-1}$ for Mariut and El Qalla drains sediment samples [67]. 


\subsection{X-Ray Analysis for Mineral Analysis of Sediments}

Figures 3-5 and Tables 4-6 showed that the sediments comprise two main minerals: silicate and carbonate that appear in some sediments profile as Mg-calcite as a result of Mg substitution [68]. Silicate minerals could be differentiated into quartz and feldspar. For El-Max Bay, the sediment sample mainly comprises calcium 91\%, silicate 4.2\%, 1.7\% sulfides and 1.4\% Manganese. In El-Qalaa, the sediment sample comprises of silicate 70.7\%, Manganese $6.7 \%$ and $6.3 \%$ Calicum. In mariut Lake, the sediment sample mainly comprises of Silicate $46.9 \%$, calcium $18.1 \%$ and $13.4 \%$ Manganese. The X-Ray analysis results peformed for the present study reflecting predominantly of Calcium, Silicate and Manganese minerals.

\subsection{Differential Thermal Analysis (DTA)}

Differential thermal analysis is a thermoanalytic technique. In DTA, the material under study and an inert reference are made to undergo identical thermal cycles, while recording any temperature difference between sample and reference [69]. The DTA is illustrated in Figure 6 for station 4 of El-Mex Bay, El-Qalaa and Mariut Lake Sediment samples. El Mex Bay sample showed endothermic decomposition to $\mathrm{CaO}$ and $\mathrm{CO}_{2}$ at $700^{\circ} \mathrm{C}-900^{\circ} \mathrm{C}$ [70] (Sestak, 2005). The small peaks observed for El-Qalaa drain and Mariout lake, samples indicated the presence of quartz $\left(\mathrm{SiO}_{2}\right)$ because of the $\alpha$ to $\beta$ quartz inversion. The calculated order values from the peak asymmetry method [71] are ( $\mathrm{n}=0.46,1.45$ and 1.45) for El-Mex Bay, El-Qalaa and Mariout Lake sediment samples. The order of reaction indicates that the reactions are not of simple manner but the reactions proceeded in complicated mechanisms. The $-\Delta \mathrm{S} \#$ values support that the sediments are more ordered and such structures are hardly subjected to decomposition. The small collision factor values (Z), support the view of the extra stability of these sediments [72] [73].

DTA figures gave steps due to dehydration, rearrangement and decarbonation. Table 7 illustrated that the order of the reactions is $\sim 1$. The $-\Delta \mathrm{S}$ values support that the sediments are more ordered. So, such structures are hardly for decomposition. This is well verified by $-\Delta \mathrm{H}$ values. The $-\Delta \mathrm{S}$ values are nearly of the same magnitude, revealing that the composition of the sediment samples is the same independent of the region of the studied area. The small collision factor values, Z, support the view of the extra stability of these sediments [18] [74] [75].

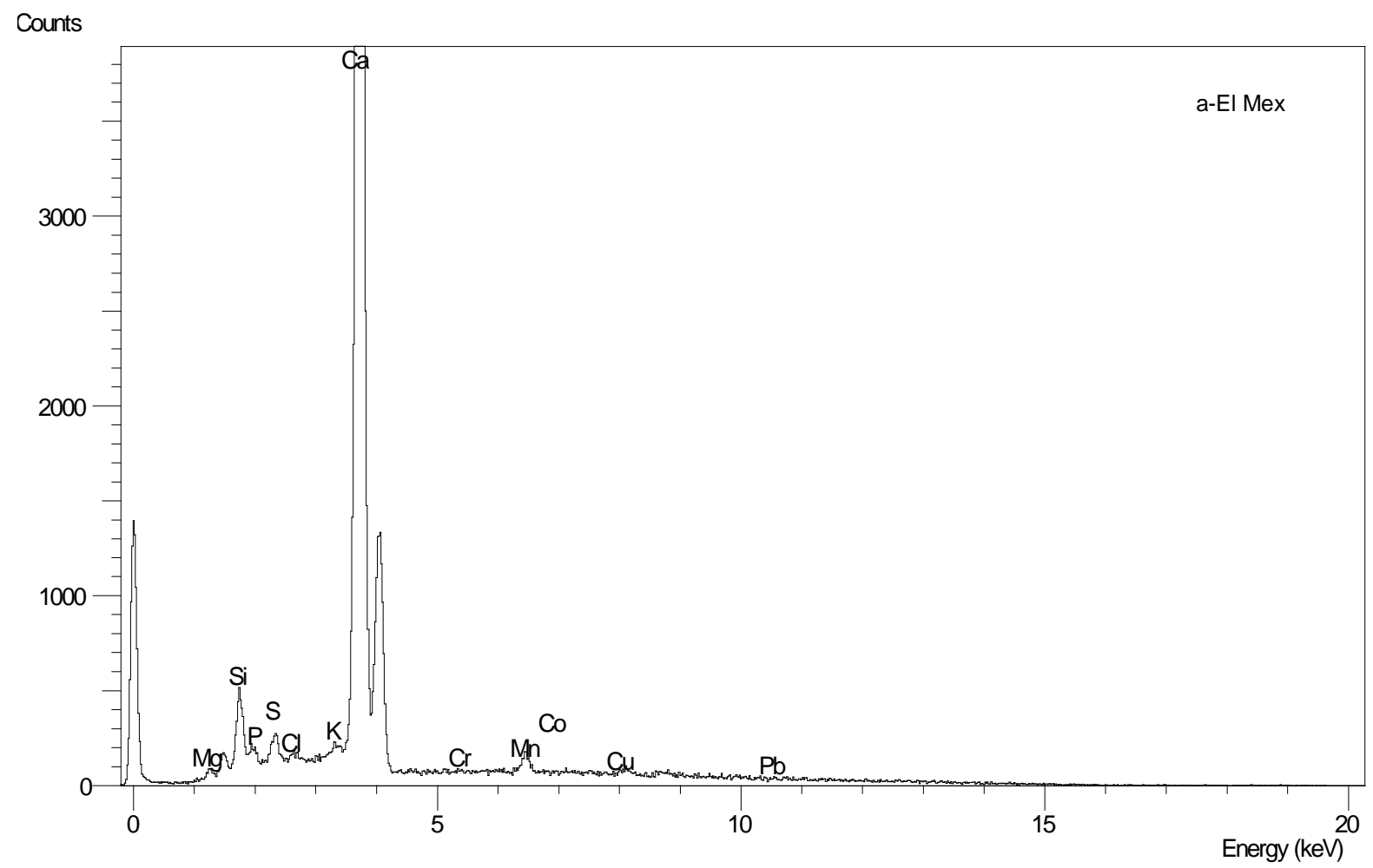

Figure 3. X-Ray analysis peaks for a) El-Mex Bay. 


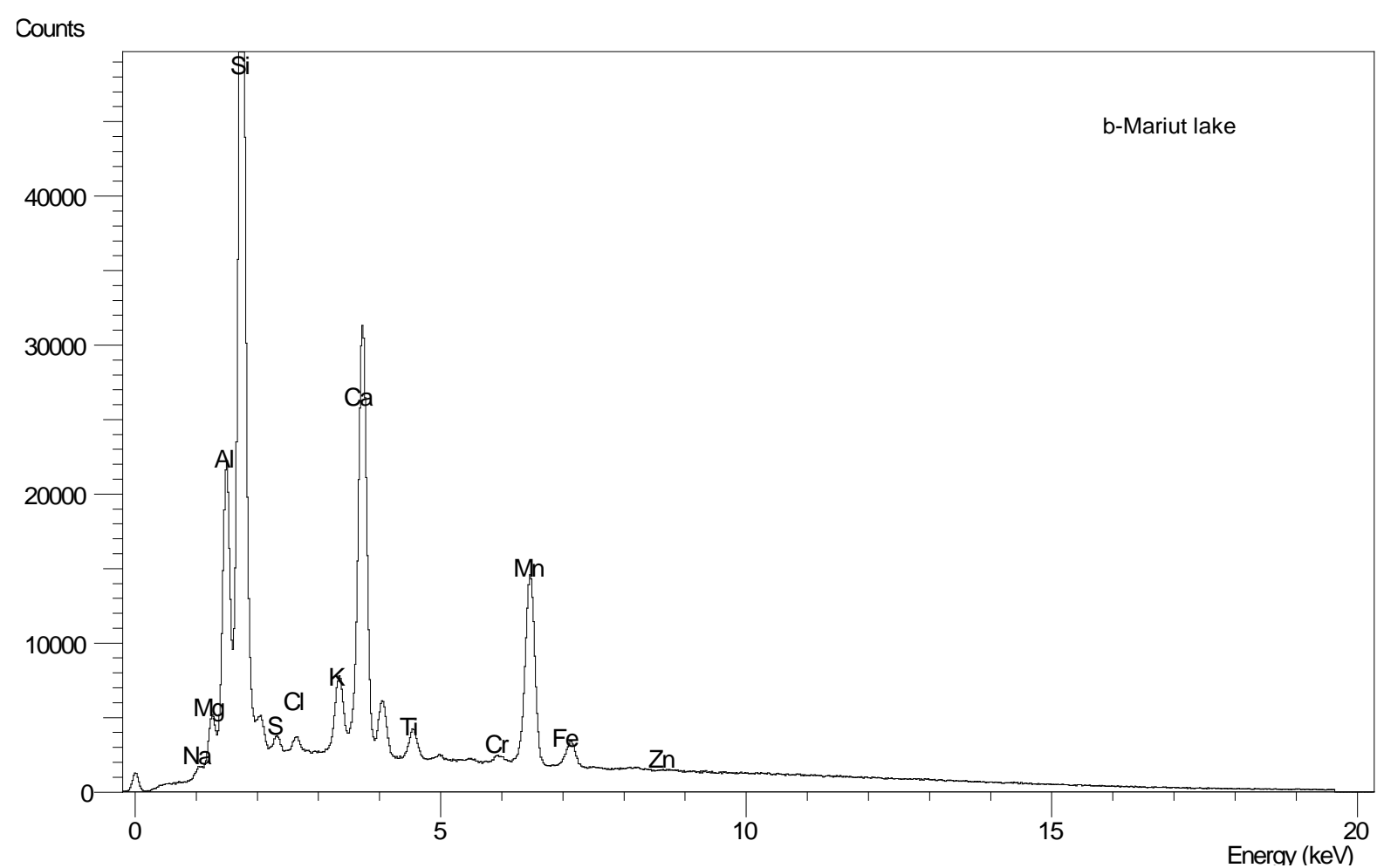

Figure 4. X-Ray analysis peaks for b) Mariut lake.

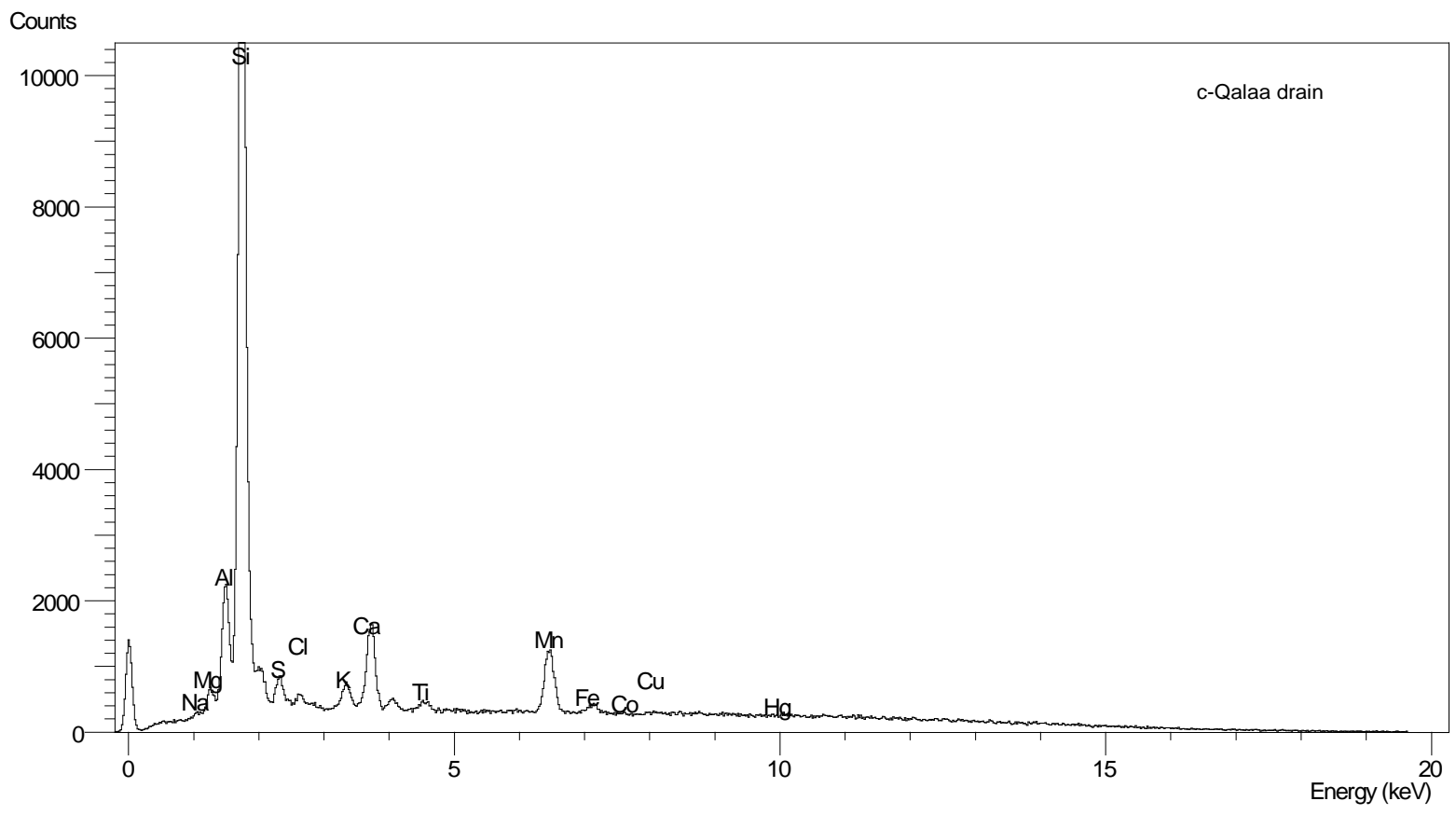

Figure 5. X-Ray analysis peaks for c) El Qalaa drain.

Table 4. X ray for El Mex Bay station 4.

\begin{tabular}{cccccccccccc}
\hline Label & $\mathrm{Mg}$ & $\mathrm{Si}$ & $\mathrm{P}$ & $\mathrm{S}$ & $\mathrm{Cl}$ & $\mathrm{Ca}$ & $\mathrm{Mn}$ & $\mathrm{Co}$ & $\mathrm{Cu}$ & $\mathrm{Pb}$ \\
\hline \% Total & 0.5 & $\mathbf{4 . 2}$ & 0.3 & 1.7 & 0.3 & $\mathbf{9 1}$ & 1.4 & 0.2 & 0.5 & 0.1
\end{tabular}


Table 5. X ray analysis for Mariut lake.

\begin{tabular}{cccccccccccccc}
\hline Label & $\mathrm{Na}$ & $\mathrm{Mg}$ & $\mathrm{Al}$ & $\mathrm{Si}$ & $\mathrm{S}$ & $\mathrm{Cl}$ & $\mathrm{K}$ & $\mathrm{Ca}$ & $\mathrm{Ti}$ & $\mathrm{Cr}$ & $\mathrm{Mn}$ & $\mathrm{Fe}$ & $\mathrm{Zn}$ \\
\hline \% Total & 0.3 & 1.7 & 12.4 & $\mathbf{4 6 . 9}$ & 0.6 & 0.7 & 3.1 & $\mathbf{1 8 . 1}$ & 1.5 & 0.4 & $\mathbf{1 3 . 4}$ & 0.9 & 0.1 \\
\hline
\end{tabular}

Table 6. X ray analysis for El Qalaa drain.

\begin{tabular}{ccccccccccccccccccc}
\hline Label & $\mathrm{Na}$ & $\mathrm{Mg}$ & $\mathrm{Al}$ & $\mathrm{Si}$ & $\mathrm{S}$ & $\mathrm{Cl}$ & $\mathrm{K}$ & $\mathrm{Ca}$ & $\mathrm{Ti}$ & $\mathrm{Cr}$ & $\mathrm{Mn}$ & $\mathrm{Fe}$ & $\mathrm{Co}$ & $\mathrm{Cu}$ & $\mathrm{Hg}$ \\
\hline \% Total & 0.2 & 1.4 & 8.1 & $\mathbf{7 0 . 7}$ & 1.9 & 0.9 & 1.6 & $\mathbf{6 . 3}$ & 0.5 & 0.2 & $\mathbf{6 . 7}$ & 0.7 & 0.2 & 0.4 & 0.3 \\
\hline
\end{tabular}

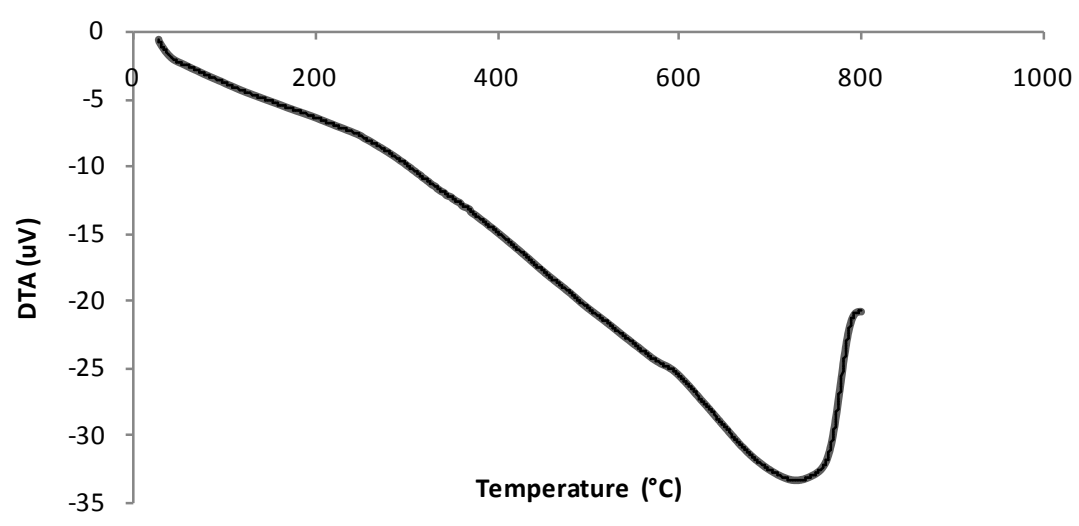

DTA-El-Max bay

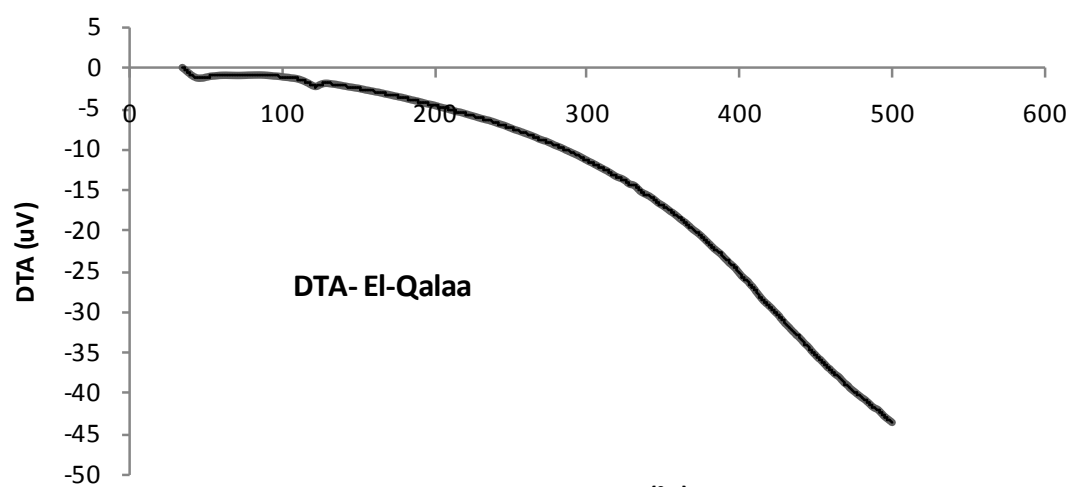

Temperature $\left({ }^{\circ} \mathrm{C}\right)$

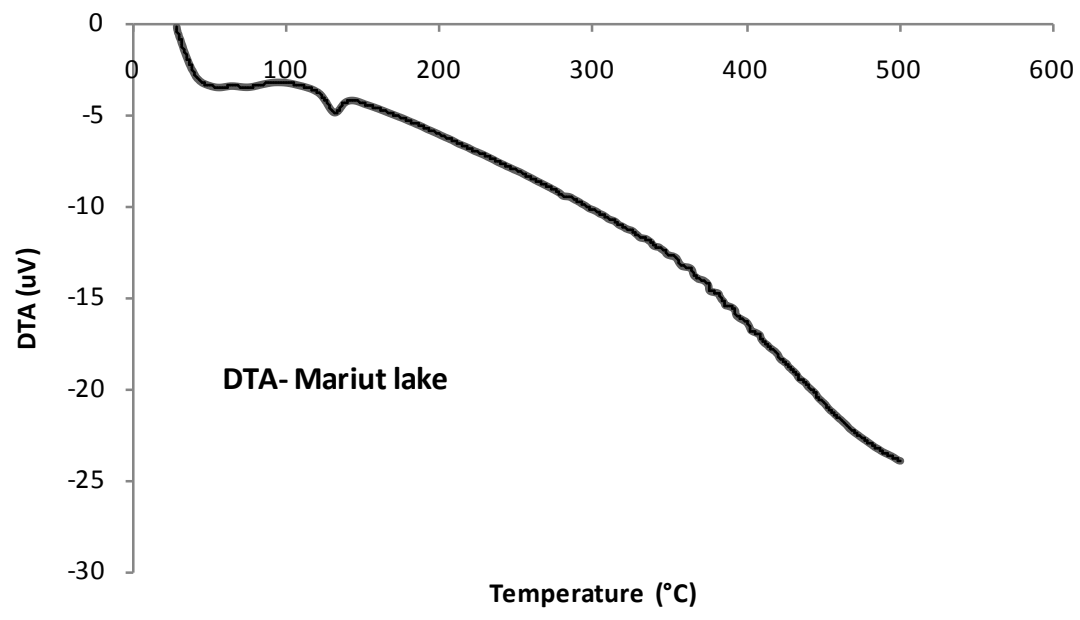

Figure 6. The DTA peaks for station 4 of El-Mex Bay, El-Qalaa and mariut lake sediment. 
Table 7. Thermodynamic parameters (DTA) for sediment samples.

\begin{tabular}{|c|c|c|c|c|c|c|c|c|}
\hline \multirow[t]{2}{*}{ Sample } & \multicolumn{5}{|l|}{ Peak } & \multirow{2}{*}{$-\Delta \mathbf{S} \#$} & \multirow{2}{*}{$-\Delta \mathbf{H} \#$} & \multirow{2}{*}{$\Delta \mathbf{G} \#$} \\
\hline & Temp $\left({ }^{\circ} \mathrm{C}\right)$ & $\mathbf{n}$ & $\alpha$ & $\operatorname{Tm}(\mathbf{K})$ & $\mathbf{Z}$ & & & \\
\hline & & & & & & $\left(\mathbf{k j} \cdot \mathrm{K}^{-1} \cdot \mathrm{mol}^{-1}\right)$ & $(\mathrm{kJ} / \mathrm{mol})$ & $\left(\mathrm{kJ} / \mathrm{mol}^{-1}\right)$ \\
\hline El-Mex & 768.97 & 0.46 & 0.76 & 1041.97 & 0.98 & 0.26 & 256.69 & 9.19 \\
\hline El-Qalaa & 122.97 & 1.45 & 0.56 & 395.97 & 2.86 & 0.24 & 85.58 & 8.56 \\
\hline Mariut lake & 127.36 & 1.45 & 0.56 & 400.36 & 2.82 & 0.24 & 86.70 & 8.57 \\
\hline
\end{tabular}

\section{Conclusion}

The inorganic nutrient concentrations in the BW column of El Mex Bay and its surround drains indicate that this area suffers from acute eutrophication, resulting from a great amount of anthropogenic nutrients entering the sea through numerous land-based sources. Continuous burial and decomposition of organic matter in the topmost layer of the sediment is the main reason for the high nutrient concentrations in the PW compared to those in the OBW. The variations in concentrations between sites can be mainly attributed to variations in supply and input of reactive organic matter. Nutrient diffusive fluxes calculated in the present study during spring, 2010 from sediments had averages of $-7.24,-1.36,-7.86$ and -1.33 , however in the drains were $-34.39,-32.28,-53.20$ and $-117.6 \mathrm{mg} \cdot \mathrm{m}^{-2} \cdot \mathrm{day}^{-1}$ for $\mathrm{NO}_{3}^{-}, \mathrm{NO}_{2}^{-}, \mathrm{PO}_{4}^{3-}$ and $\mathrm{SiO}_{4}^{4-}$, respectively. Based on IR X-ray diffraction and DTA sediment samples were mainly composed of calcite, Mg-calcite and silicate.DTA curves are used to evaluate and discuss different kinetic parameters (n, $\mathrm{Ea}^{\#}, \Delta \mathrm{G}^{\#}, \Delta \mathrm{H}^{\#}, \Delta \mathrm{S}^{\#}, \mathrm{Z}$ and Tm) support the view of the extra stability of these sediments.

\section{References}

[1] Shriadah, M.A. and Emara, H.I. (1996) Heavy Metals (Iron, Manganese, Nickel, Cadmium, and Lead) in the Sediments from the Eastern Harbor and El-Mex Bay of Alexandria, Egypt. Proceedings of the 6th International Symposium of Environmental Protection Is a Must, Alexandria, 21-23 May, 916-927.

[2] Shriadah, M.A., Hosny, I. and Emara, H.I. (1999) Heavy Metals in Pore Water of Two Semi-Closed Coastal Areas; Alexandria (Egypt). Pakistan Journal of Marine Science, 8, 107-113.

[3] Abdel-Fatah, L., Fahmy, M.A. and Shriadah, M.A. (2003) Zn, Cu, Cd, Pb and Hg in the Egyptian Coastal Sediments along the Mediterranean Sea. Association for Modelling and Simulation Techniques in Enterprise. (AMSE) (France), 64, 55-69.

[4] Shakweer, L., Shriadah, M.A., Fahmy, M.A. and Abdel Fattah, L. (2006) Distributions and Concentrations of Trace Elements along the Mediterranean Coastal Water of Egypt. Egyptian Journal of Aquatic Research, 32, 95-127.

[5] Okbah, M.A., Ibrahim, A.M.A. and Gamal, M.N.M. (2013) Environmental Monitoring of Linear Alkylbenzene Sulfonates and Physicochemical Characteristics of Seawater in El-Mex Bay (Alexandria, Egypt). Environmental Monitoring and Assessment, 185, 3103-3115. http://dx.doi.org/10.1007/s10661-012-2776-9

[6] Shreadah, M.A., Said, T.O., Abdel Moniem, M.I., Eiman, M.I., Fathallah, E.M.I. and Mahmoud, M.E. (2011) PAHsin Sediments along the Semi-closed Areas of Alexandria, Egypt. Journal of Environmental Protection, 2, 700-709. http://dx.doi.org/10.4236/jep.2011.26081

[7] Shobier, A.H., Abdel Ghani, S.A. and Shreadah, M.A. (2011) Distribution of Total Mercury in Sediments of Four Semi-Enclosed Basins along the Mediterranean Coast of Alexandria. Egyptian Journal of Aquatic Research, 37, 1-11.

[8] Emara, H.I., Shriadah, M.A., Moustafa, Th.H. and El-Deek, M.S. (1995) Trace Metals-Nutrient Salts Relationship in Coastal Seawater of Alexandria. Proceedings of the MEDCOAST, Tarragona, 24-27 October 1995, 1457-1464.

[9] Shriadah, M.A. (1998) Metals Pollution in Marine Sediments of the United Arab Emirates Creeks along the Arabian Gulf Shoreline. Bulletin Environmental Contamination and Toxicology, 60, 417-424. http://dx.doi.org/10.1007/s001289900642

[10] Shriadah, M.A. (1999) Occurrence of Trace Metals in the Arabian Gulf and the Gulf of Oman Sediments off the United Arab Emirates. OEBAILLA, 25, 43-52.

[11] Shriadah, M.A. (1999) Heavy Metals in Mangrove Sediments of the United Arab Emirates Shoreline (Arabian Gulf). Water, Air and Soil Pollution, 116, 523-534.

[12] Shriadah, M.A. (2000) Levels and Distributions of Petroleum Hydrocarbons in the Coastal Waters and Sediments of 
the United Arab Emirates in the Arabian Gulf and the Gulf of Oman. Water, Air and Soil Pollution, 119, 247-256.

[13] Shriadah, M.A. (2000) Chemistry of the Mangrove Waters and Sediments along the Arabian Gulf Shoreline of the United Arab Emirates. Indian Journal of Marine Science, 29, 224-229.

[14] Shreadah, M.A., Said, T.O., Othman, I.M., Fathallah, E.M.I. and Mahmoud, M.E. (2012) Polychlorinated Biphenyls and Chlorinated Pesticides in Sediments along the Semi-Closed Areas of Alexandria, Egypt. Journal of Environmental Protection, 3, 141-149.

[15] Masoud, M.S. and Said, T.O., El-Zokm, G. and Shreadah, M.A. (2012) Assessment of Heavy Metals Contamination in Surface Sediments of the Egyptian Red Sea Coasts. Australian Journal of Basic and Applied Sciences, 6, 44-58.

[16] Abdel Ghani, S.A., El Zokm, G.M., Shobier, A.H., Othman, T.S. and Shreadah, M.A. (2013) Metal Pollution in Surface Sediments of Abu Qir Bay and the Eastern Harbor of Alexandria, Egypt. Egyptian Journal of Aquatic Research, 39, 1-12. http://dx.doi.org/10.1016/j.ejar.2013.03.001

[17] Abdel Ghani, S.A., Shobier, A.H. and Shreadah, M.A. (2013) Assessment of Arsenic and Vanadium Pollution in Surface Sediments of the Egyptian Mediterranean Coast. Journal of Environmental Technology and Management, 16, 82101. http://dx.doi.org/10.1504/IJETM.2013.050673

[18] El Zokm, G.M., Abdel Ghani, S.A., Shobier, A.H., Othman, T.S. and Shreadah, M.A. (2013) IR Spectroscopic Investigation, X-Ray Structural Characterization, Thermal Analysis Decomposition and Metal Content of Sediment Samples along Egyptian Mediterranean Coast. World Applied Sciences Journal, 23, 823-836.

[19] Shreadah, M.A., Shobier, A.H., Abdel Ghani, S., El-Zokm, G.M. and Said, T.O. (2015) Major Ions Anomalies and Contamination Status by Trace Metals in Sediments from Two Hot Spots along the Mediterranean Coast of Egypt. Environmental Monitoring and Assessment, 187, 280. http://dx.doi.org/10.1007/s10661-015-4420-y

[20] El Zokm, G.M., Okbah, M.A. and Younis, A.M. (2015) Assessment of Heavy Metals Pollution Using AVS-SEM and Fractionation Techniques in Edku Lagoon Sediments, Mediterranean Sea. Journal of Environmental Science and Health, Part A Toxic/Hazardous Substances and Environmental Engineering, 50, 571-584.

[21] Shriadah, M.A. and Emara, H.I. (1992) Iron, Manganese, Nickel, Lead, and Cadmium in Fish and Crustacea from the Eastern Harbor and El-Mex Bay of Alexandria. Bulletin High Institute of Public Health, 22, 515-525.

[22] Shriadah, M.A. (1992) Trace Elements Concentration in Fish Samples from Alexandria Region. Bulletin High Institute of Public Health, 22, 437-444.

[23] Shriadah, M.A. (2001) Petroleum Hydrocarbons Concentrations in Arabian Gulf Fish Tissues. Bulletin Environmental Contamination and Toxicology, 67, 560-567. http://dx.doi.org/10.1007/s001280160

[24] Tayel, F.R. and Shriadah, M.A. (1996) Fe, Cu, Mn, Pb and Cd in Some Fish Species from the Western Harbor of Alexandria, Egypt. Bulletin National Institute of Oceanography \& Fisheries, A. R. E., 22, 85-96.

[25] Said, T.O., Farag, R.S., Younis, A.M. and Shriadah, M.A. (2006) Organotin Species in Fish and Bivalves Samples Collected from the Egyptian Mediterranean Coast of Alexandria, Egypt. Bulletin of Environmental Contamination and Toxicology, 77, 451-458. http://dx.doi.org/10.1007/s00128-006-1086-8

[26] El Deeb, M.K.Z., Said, T.O., El Naggar, M.H. and Shreadah, M.A. (2007) Distribution and Sources of Aliphatic and Polycyclic Aromatic Hydrocarbons in Surface Sediments, Fish and Bivalves of Abu Qir Bay (Egyptian Mediterranean Sea). Bulletin of Environmental Contamination and Toxicology, 78, 373-379. http://dx.doi.org/10.1007/s00128-007-9173-z

[27] Shreadah, M.A., Said, T.O., Abd El Ghani, S.A. and Ahmed, A.M. (2008) Alkyllead and Alkyltin Species in Different Fishes Collected from the Suez Gulf, Egypt. Egyptian Journal of Aquatic Research, 34, 64-73.

[28] Fathy, S.A.H., Abdel Hamid, F.A., Shreadah, M.A., Mohamed, L.M. and El Gazar, M. (2012) Effect of Some Environmental Pollutants on Enzymatic and Total Antioxidant Activities in Tilapia Niloticus. Blue Biotechnology Journal, 1, 433-443.

[29] Fathy, S.A.H., Abdel Hamid, F.A., Shreadah, M.A., Mohamed, L.M. and El Gazar, M. (2012) Application of Principal Component Analysis for Developing Water Quality Index for Selected Coastal Areas of Alexandria Egypt. Recourses and Environment Journal, 2, 297-305.

[30] Shreadah, M.A., Fahmy, M.A. and Abdel Fattah, L. (2015) Heavy Metals in Some Fish Species and Bivalves from the Mediterranean Coast of Egypt. Journal of Environmental Protection, 6, 1-9. http://dx.doi.org/10.4236/jep.2015.61001

[31] Wei, X., Ni, P. and Zhan, H. (2013) Monitoring Cooling Water Discharge Using Lagrangian Coherent Structures: A Case Study in Daya Bay, China. Marine Pollution Bulletin, 75, 105-113. http://dx.doi.org/10.1016/j.marpolbul.2013.07.056

[32] Liui, S.M., Zhang, J. and Jiang, W.S. (2003) Pore Water Nutrient Regeneration in Shallow Coastal Bohai Sea, China. Journal of Oceanography, 59, 377-385. http://dx.doi.org/10.1023/A:1025576212927

[33] Shreadah, M.A., Masoud, M.S., Khattab, A.M. and El Zokm, G.M. (2014) Impacts of Different Drains on the Seawater 
Quality of El-Mex Bay (Alexandria, Egypt). Journal of Ecology and the Natural Environment, 8, 287-303.

[34] Aston, S.R. and Chester, R. (1976) Basic Properties and Processes in Estuarine Chemistry. In: Burton, J.D. and Liss, P.S., Eds., Estuarine Chemistry, Academic Press, London and New York.

[35] Emara, H.I. and Shriadah, M.A. (1991) Manganese, Iron, Cobalt, Nickel, and Zinc in the Eastern Harbor and El-Mex Bay Waters (Alexandria). Proceedings of the Symposium on Market Chemistry in the Arab Region, Suez, April 1991, 97-112.

[36] Shriadah, M.A. and Emara, H.I. (1992) Major Cations and Alkalinity in the Eastern Harbor and El-Mex Bay. Bulletin Faculty of Science, Alexandria University, 32, 156-174.

[37] Emara, H.I., Shriadah, M.A., Maoustafa, T.H. and El-Deek, M.S. (1992) Effects of Sewage and Industrial Wastes on the Chemical Characterstics of the Eastern Harbor and El-Max Bay Waters of Alexandria, Egypt. Science of the Total Environment, 112, 773-784.

[38] Said, M.A., El-Deek, M.S., Mamoud, T.H. and Shriadah, M.A. (1994) Effect of Pollution on the Hydrochemical Characteristics of Different Water Types in El-Mex Bay Area West of Alexandria, Egypt. Acta Adriatica, 34, 9-19.

[39] Tayel, F.R., Fahmy, M.A. and Shriadah, M.A. (1996) Studies on the Physicochemical Characteristics of Mex Bay and New Dekhaila Harbor Waters of Alexandria, Egypt. Bulletin National Institute of Oceanography \& Fisheries, A. R. E., 22, 1-18.

[40] Fahmy, M.A., Tayel, F.R. and Shriadah, M.A. (1997) Spatial and Seasonal Variations of Dissolved Trace Metals in Two Contaminated Basins of the Coastal Mediterranean Sea, Alex Andria, Egypt. Bulletin Faculty of Science, Alexandria University, 37, 187-198.

[41] Shriadah, M.A., Said, T.O., Younis, A.M. and Farag, R.S. (2006) Physical-Chemical Characteristics of the SemiClosed Areas along the Mediterranean Coast of Alexandria, Egypt. Egyptian Journal of Aquatic Research, 32, 38-48.

[42] Shriadah, M.A., Said, T.O., Younis, A.M. and Farag, R.S. (2006) Speciation of Organotin Compounds in Sediments of Semi-Closed Areas along the Mediterranean Coast of Alexandria. Chemistry and Ecology, 22, 395-404.

[43] Strickland, H.D. and Parsons, T.R. (1972) A Practical Handbook of Seawater Analysis. Fisheries Research Board of Canada Bulletin, 157, 31.

[44] Manheim, F.T. (1966) A Hydraulic Squeezer for Obtaining Interstitial Water from Consolidated and Unconsolidated Sediments. US Geological Survey Professional Paper, 550.C, 256-261.

[45] Patterson, C.C. and Settle, D.M. (1975) The Reduction of Orders of Magnitude Errors in Lead Analysis of Biological Materials and Natural Waters by Evaluation and Controlling the Extent and Sources of Industrial Lead Concentration Introduces during Sample Collecting Handling and Analysis. Proceedings of the 7th IMR Symposium, Gaithersburg, 7-11 October 1974.

[46] Klump, J.V. (1987) Biological Cycling in an Organic-Rich Coastal Marine Basin 5. Sedimentary Nitrogen and Phosphorus Budgets Based upon Kinetic Models, Mass Balances and the Stoichiometry of Nutrient Regeneration. Geochimica Cosmochimica Acta, 51, 1161-1173.

[47] Folk, R.L. (1974) Petrology of Sedimentary Rocks. Hemphill Publishing Co., Austin, 170 p.

[48] Krumbein, W.C. and Pettijohn, F.J. (1938) Manual of Sedimentary Petrography. D. Appleton-Century, New York, 549 p.

[49] Krom, M.D. and Berner, R.A. (1980) The Diffusion Coefficients of Sulfate, Ammonium, and Phosphate Ions in Anoxic Marine Sediments. Limnology and Oceanography, 25, 327-337. http://dx.doi.org/10.4319/lo.1980.25.2.0327

[50] Zhang, L., Wang, L., Yin, K., Lü Y., Zhang, D., Yang, Y. and Huang, X. (2013) Pore Water Nutrient Characteristics and the Fluxes across the Sediment in the Pearl River Estuary and Adjacent Waters, China. Estuarine Coastal and Shelf Science, 133, 182-192. http://dx.doi.org/10.1016/j.ecss.2013.08.028

[51] Berner, R.A. (1980) Early Diagenesis: A Theoretical Approach. Princeton University Press, Princeton, 241 p.

[52] Sakamaki, T., Kim, J.H., Chiba, N., Nishimura, O. and Sudo, R. (1999) Behavior of Nitrogen of Tidal Flate in Tide Time. Proceedings of the MEDCOAST 99-EMECS 99 Joint Conference, Antalya, 9-13 November 1999.

[53] Henderson-Seller, B. and Markland, H.R. (1987) Decaying Lakes-The Origins and Control of Cultural Eutrophication. Wiley, New York, 5-153.

[54] Smith, S.V., Swaney, D.P., Talaue-McManus, L., Bartley, J.D., Sandhei, P.T., McLaughlin, C.J., Dupra, V.C., Crossland, C.J., Buddemeier, R.W. and Maxwell, B.A. (2003) Humans, Hydrology, and the Distribution of Inorganic Nutrient Loading to the Ocean. Bioscience, 53, 235-245. http://dx.doi.org/10.1641/0006-3568(2003)053[0235:HHATDO]2.0.CO;2

[55] Cloer, J.E. (2001) Our Evolving Conceptual Model of the Coastal Eutrophication Problem. Marine Ecology Progress Series, 210, 223-253. http://dx.doi.org/10.3354/meps210223

[56] Nessim, R.B., Tadros, H.R.Z. and Abou Taleb, A.E. (2007) Pore water Chemistry of Alexandria Eastern Harbor 
(2004-5). Proceeding of the English International Conference on the Mediterranean Coastal Environment, Alexandria, 13-17 November 2007.

[57] Faragallah, H.M. (1995) Sediment-Water Interface Chemistry in the Eastern Harbor, Alexandria, Egypt. Master's Thesis, Faculty of Science, Alexandria University, Alexandria, 277 p.

[58] Abu El khair, E., Fahmy, M.A. and Aly Eldeen, M.A. (2010) The Role of Sediment Pore Waters in the Fertility of Abu Qir Bay, Egypt. Egyptian Journal of Aquatic Research, 36, 523-529.

[59] Khairy, H.M., Faragallah, H.M, Hussein, N.R. and Dorgham, M.M. (2014) Environmental Characteristics and Nutritional Level of Chronically Eutrophic Bay on Alexandria Sea Coast, Egypt. Indian Journal of Geo-Marine Sciences, 43.

[60] Delange, G.J. (1986) Chemical Composition of Interstitial Water in Cores from Nares Abyssal Plain (Western North Atlantic). Oceanologica Acta, 9, 159-168.

[61] Noel, M.H. (1999) Nutrient Release from Sediment in the Changjiang Estuary. Proceedings of the MEDCOAST 99-EMECS 99 Joint Conference, Antalya, 9-13 November 1999.

[62] Smolander, K., Saastamoninen, A. and Ahttgren, M. (1989) Determination of Talc in Geological Samples by Infrared Spectrometry. Analytica Chimica Acta, 217, 353-358. http://dx.doi.org/10.1016/S0003-2670(00)80417-1

[63] El-Shabiny, A.M., Hammad, S.M., Ibrahim, I.A. and Ismail, A.K. (1996) Combined Thermal and Structural Study of Some Egyptian Bentonitic Clays. Journal of Thermal Analysis, 46, 1421-1435. http://dx.doi.org/10.1007/BF01979255

[64] Degens, E.T. (1976) Molecular Mechanisms on Carbonate, Phosphate, and Silica Deposition in the Living Cell. Springer-Verlag, Berlin Heidelberg and New York, 110-116.

[65] Frost, R.L., Lack, D.A., Paroz, G.N. and Tran, T.H.T. (1999) New Techniques for Studying the Intercalation of Kaolinites from Georgia with Formamide. Clays and Clay Minerals, 47, 297-303. http://dx.doi.org/10.1346/CCMN.1999.0470305

[66] Silverstein, R.M., Bassler, G.C. and Morrill, T.C. (1991) Spectrometric Identification of Organic Compounds. John Wiley, New York, 109-130.

[67] Ece, Ö.I., Coban, F., Güngör, N. and Suner, F. (1999) Clay Mineralogy and Occurrence of Ferrian Smectites between Serpentinite Saprolites and Basalts in Biga Peninsula, Northwest Turkey. Clays and Clay Minerals, 47, 241-251.

[68] Goldsmith, J.R., Graf, D.L. and Heard, H.C. (1961) Lattice Constants of the Calcium-Magnesium Carbonates. American Mineralogist, 43, 84-101.

[69] Bhadeshia, H.K.D.H. (2002) Thermal Analyses Techniques. Differential Thermal Analysis. University of Cambridge, Material Science and Metallurgy. www.msm.cam.ac.uk/phase-trans/2002/Thermal1.pdf

[70] Sestak J. (2005) Science of Heat and Thermo Physical Studies: A Generalized Approach to Thermal Analysis. Elsevier Science and Technology Books, 344 p.

[71] Kissinger, E. (1957) Reaction Kinetics in Differential Thermal Analysis. Analytical Chemistry, 29, 1702-1706. http://dx.doi.org/10.1021/ac60131a045

[72] Piloyan, G.O., Ryabchikov, I.D. and Novikova, O.S. (1966) Determination of Activation Energies of Chemical Reactions by Differential Thermal Analysis. Nature, 212, 1229.

[73] Tunney, J. and Detellier, C. (1994) Preparation and Characterization of an 84A Hydrate of Kaolinite. Clays and Clay Minerals, 42, 473-480. http://dx.doi.org/10.1346/CCMN.1994.0420414

[74] Shreadah, M.A., Masoud, M.S., Tarek, O., Said, T.O. and El Zokm, G. (2008) Application of IR, X-Ray, TGA and DTA to Determine the Mineral Composition of the Sediments and Study of Reaction Kinetics along the Egyptian Red Sea Coasts. Egyptian Journal of Aquatic Research, 34, 83-95.

[75] Masoud, M.S., El-Samra, M.I., EL-Sarraf, W.M. and El-Sadawy, M.M. (2009) Thermal, Infrared and X-Ray Diffraction Properties of Sediment Samples from El-Mex Bay, Alexandria, Egypt. International Journal of Pure and Applied Chemistry, 4, 11-19. 